\title{
Application of the nursery-role hypothesis to an estuarine fish
}

\author{
Richard T. Kraus ${ }^{1, *}$, David H. Secor ${ }^{2}$ \\ ${ }^{1}$ Department of Marine Biology, Texas A\&M University. 5007 Avenue U, Galveston, Texas 77551, USA \\ ${ }^{2}$ University of Maryland Center for Environmental Science, Chesapeake Biological Laboratory, One Williams Street, \\ Solomons, Maryland 20688, USA
}

\begin{abstract}
In this paper, we address a recent article by Beck et al. (2001, Bioscience 51:633-641), in which it was proposed that the value of a juvenile fish habitat could be most efficiently measured as the production of adults from each juvenile habitat on a per area basis. Based upon retrospective microchemical analysis of otoliths, we calculated this metric (nursery value) for tidal freshwater and brackish littoral habitats of an estuarine fish, white perch Morone americana, in the Patuxent River estuary, Maryland (USA). In dominant year-classes of the population, brackish habitats had the highest nursery value, whereas in all other year-classes, freshwater habitats had the highest nursery value. This result highlights the importance of inter-annual variability in habitat use, and consequently presents a challenging trade-off for applying the nursery-role hypothesis to facilitate habitat conservation and management. Despite this limitation, the nursery-role hypothesis provides an enriched and much needed perspective on population connectivity.
\end{abstract}

KEY WORDS: Nursery-role - Habitat conservation · Estuarine dependency · Otolith chemistry · Chesapeake

Resale or republication not permitted without written consent of the publisher

\section{INTRODUCTION}

One of the foremost issues facing aquatic habitat managers and conservationists is how to prioritize actions among habitats. For species with complex life cycles (e.g. egg, larval, juvenile, and adult stages), priority is usually given to those habitats that can be identified as nurseries, but until recently, an explanation of what constitutes a nursery has been ambiguous (Beck et al. 2001). Beck et al. (2001) defined a nursery-role concept for marine and estuarine fishes and invertebrates, and formulated a hypothesis that provides a more objective and useful approach to evaluating habitats as nurseries. While their proposal has great intuitive appeal and has had a high impact (already cited $>58$ times in the primary literature), it has been difficult to test empirically. Here, we used otolith approaches to test Beck et al.'s (2001) nursery-role hypothesis, and we highlight important limitations and opportunities for the future implementation of this approach to nursery habitat assessment.
Beck et al. (2001) defined the nursery-role concept to emphasize production of adults per unit area of juvenile habitat. The nursery-role hypothesis is that some 'juvenile habitats contribute disproportionately to the production of individuals that recruit to adult populations' and that nurseries are only a subset of juvenile habitats which lead to above average production of adults. Though, in general, the term nursery has been applied to all juvenile habitats (rather than a subset), Beck et al. (2001) stress that this use of the term provides no useful basis for conservation, enhancement, and restoration goals. Most importantly, this nursery-role concept provides a way to evaluate putative nurseries. To make this evaluation, one must quantify the percent contribution to productivity of adults per unit area of juvenile habitat (Beck et al. 2001). One way to measure this quantity is to estimate the percent of adults per unit area of juvenile habitat, a metric we call nursery value. We estimated the nursery value of juvenile habitats of a small (300 to $400 \mathrm{~mm}$ total length), moderately long-lived ( 3 to $12 \mathrm{yr}$ ) estuarine fish, white perch Morone americana, in Chesapeake Bay. 


\section{MATERIALS AND METHODS}

To classify individual adult white perch according to the habitats they occupied as juveniles, we examined the trace element chemistry of otoliths (ear stones) using a method that Beck et al. (2001) identified as a promising way to test the nursery-role hypothesis. Much like tree-rings, the layered structure of otoliths can be used to retrospectively study the size and age of individual fish, and trace elements within the otolith layers are sometimes reflective of time spent in different habitats (Casselman 1982, Campana \& Thorrold 2001). Data were available from the Patuxent River estuary, where we measured strontium in otoliths to infer the juvenile habitats from which adult white perch originated. We observed that, upon metamorphosis from a pelagic freshwater larval stage, juveniles settled in 2 distinct environments: tidal freshwater (salinity <3) and oligohaline brackish (salinity 3 to 15 ) habitats (Kraus \& Secor 2004b). These patterns of habitat use were recorded in the chemistry of otoliths respectively as either no change or an increase in strontium with age or size (Fig. 1; Kraus \& Secor 2004a). In this system, juvenile white perch inhabit primarily shoal areas (shallow littoral habitats from the shoreline to depths of $2 \mathrm{~m}$; Mansueti 1964, Setzler-
Hamilton 1991). The Patuxent River estuary has a relatively stable salinity gradient along its axis, and the habitat structure (i.e. sediment composition and emergent vegetation), prey, and predators of juvenile white perch are different between tidal freshwater and brackish environments (Ulanowicz \& Neilson 1974, Boesch 1977, Odum 1988, Wagner 1999). Therefore, these areas represent the primary large-scale habitat types of juveniles, and otolith chronologies of strontium that primarily reflect changes in environmental salinity can be used to infer use of these habitats by individual white perch.

By analyzing the region of the otolith that represented the first year of life (from the core to the first annular mark), the strontium microprobe assay allowed us to estimate the fraction of adult white perch that utilized either freshwater or brackish juvenile habitats. Gillanders \& Kingsford (1996) proposed this same approach to understand the contribution of estuaries to offshore reef-fish populations, and Yamashita et al. (2000) applied this method to compare the relative recruitment of a flatfish from different juvenile habitats in 2 years. By counting annuli in otoliths, we further classified adults by year of hatching (i.e. yearclass). Like many temperate fishes, white perch have large fluctuations (over 100-fold) in juvenile abun-

a
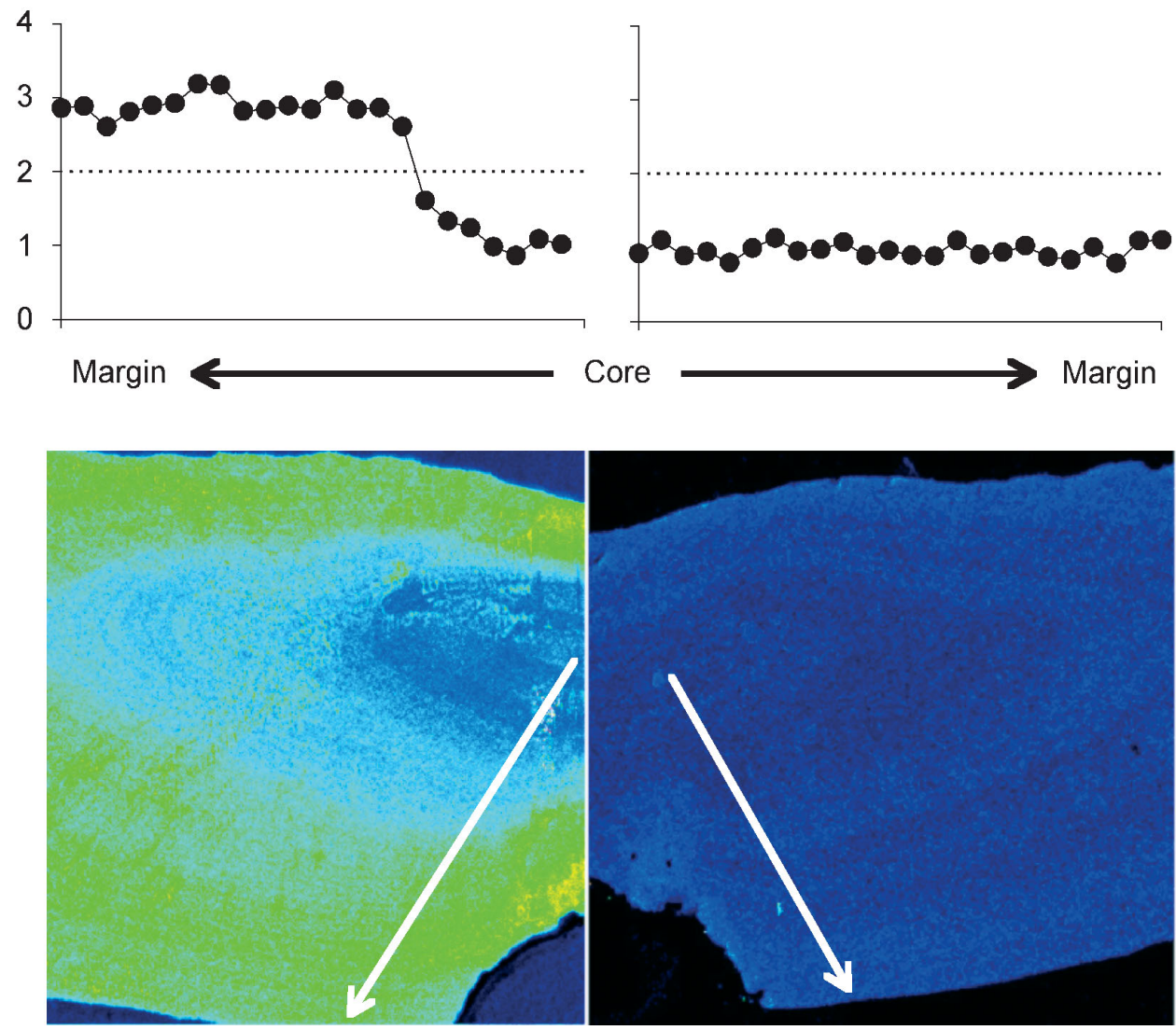

Fig. 1. Morone americana. Representative elemental fingerprints of brackish (left) and freshwater (right) juvenile white perch from the Patuxent River estuary, MD, USA. (a) Quantitative electron microprobe measurements of $\mathrm{Sr} / \mathrm{Ca}(\mathrm{mmol}$ $\mathrm{mol}^{-1}$ ) at several evenly spaced points along transects (arrows) from the core area of the otolith (early life) to the margin (time of capture). Horizontal dotted line shows the criterion (2 mmol $\mathrm{mol}^{-1}$ ) for distinguishing between time spent in brackish $(\mathrm{Sr} / \mathrm{Ca}>2)$ or freshwater (Sr/Ca < 2) habitats. (b) Xray maps of relative strontium concentration and typical transect orientation (arrows) on white perch otolith sections. Relative strontium concentration can be interpreted on a scale from blue (low $\mathrm{Sr}$ ) to green and yellow (high $\mathrm{Sr}$ ) 
dance (Kraus \& Secor 2004b); therefore, we were also interested in comparing nursery values of each habitat between dominant year-classes and other year-classes. The sample of adults $(n=363)$ collected from spring spawning aggregations over the course of $5 \mathrm{wk}$ in each of 2 years (when there was a reasonable expectation for obtaining a representative sample) was assumed to represent a random draw from the population, and dominant year-classes were determined independently from seine surveys of juveniles by the Maryland Department of Natural Resources, Annapolis (see Kraus \& Secor 2004b). Because we defined only 2 juvenile habitats, statistical inferences were made using a binomial probability distribution where the proportions in a particular category (e.g. dominant yearclasses) were compared to the overall sample proportions. Nursery values were then calculated using the proportions (and 95\% confidence limits) and static estimates of littoral area (from the shoreline to a depth of $2 \mathrm{~m}$ ) for freshwater $\left(3.3 \mathrm{~km}^{2}\right)$ and brackish $\left(34.1 \mathrm{~km}^{2}\right)$ habitats using data from Cronin \& Pritchard (1975).

\section{RESULTS AND DISCUSSION}

Over the entire sample, we estimated that each square kilometer of juvenile white perch habitat produced $2.67 \%$ of the adult population (Fig. 2), but this baseline nursery value estimate was simply a function of the total area of juvenile habitat. The most remarkable part of this analysis was the significant reversal of order in nursery value rank between dominant yearclasses and other year-classes. Dominant year-classes (3 years with the highest survey estimates of juvenile abundance: 1993, 1995, and 1996) represented twothirds of the adult sample with $96.3 \%$ of individuals originating from the brackish juvenile habitat, and in this category, brackish habitat nursery value (i.e. contribution to adults standardized by nursery area) was significantly higher than in tidal freshwater (Fig. 2). Note that these dominant year-classes were also evident from the age composition of adult samples. By comparison, the remainder of the adult sample was comprised of 8 year-classes $(1989,1991,1992,1994$, $1997,1998,1999,2000$ ) with $85.2 \%$ of individuals originating from the brackish juvenile habitat, and in this category, freshwater habitat nursery value was significantly higher than in the brackish habitat (Fig. 2). Based upon analysis of the independent surveys of juveniles (Kraus \& Secor 2004b), this reversal was primarily due to a decrease in brackish juvenile abundance between categories, rather than an increase in freshwater juvenile abundance.

We recognize that a more rigorous test of the nursery-role hypothesis would compare more than 2 habitats (Beck et al. 2001), and with white perch other

\section{a}

Fig. 2. Morone americana. Composition of adult white perch sampled from the Patuxent River estuary and classified according to juvenile habitat use (either freshwater or brackish juveniles) through analysis of otolith strontium patterns. (a) Pie charts give the composition from the pooled sample and the dominant and normal year-class groupings. Also given is a pie chart comparing the area of juvenile habitat in freshwater and brackish sections of the estuary. The 'dominant' category defines 3 yearclasses (1993, 1995, and 1996) with the highest survey estimates of juvenile abundance. The 'normal' category defines samples from 8 other year-classes in the adult sample. (b) Proportions and area estimates were used to calculate nursery value (and 95\% confidence intervals) of freshwater and brackish juvenile white perch habitats in the Patuxent River estuary. Dotted horizontal line shows the overall nursery value pooled across habitats and year-classes

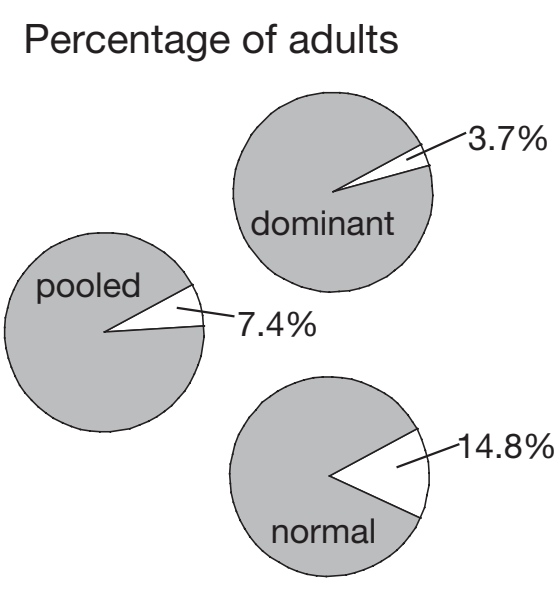

Habitat area

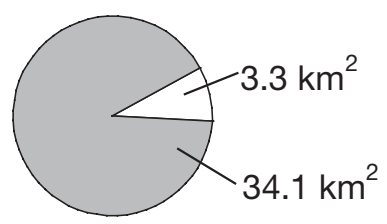

b

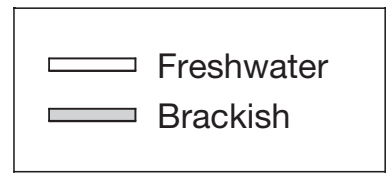

Nursery value

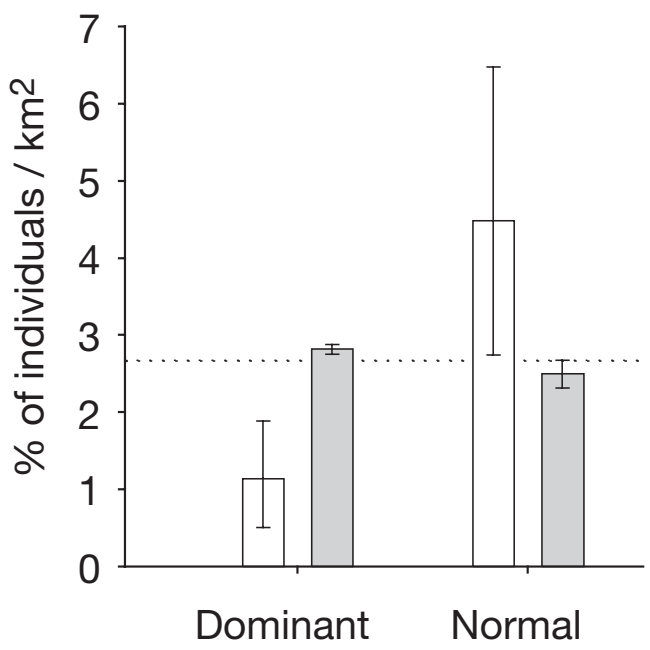


habitats to consider would represent smaller divisions of freshwater and brackish littoral environments. Still, in this relatively simple application, the reversal in the rank order of nursery value for habitats between dominant year-classes and other year-classes presents a conundrum for the nursery-role hypothesis. The high proportion in the adult sample $(92.6 \%$ overall) indicated that adult abundance was driven almost exclusively by individuals that originated from brackish juvenile habitat. Therefore, in the total sample of adults and in dominant year-classes, nursery value was higher for the brackish habitat, implying that this habitat should receive higher management and conservation priority. By comparison, in normal yearclasses, there was a significant increase in the proportion of adults originating from freshwater juvenile habitat, and some of these year-classes were represented exclusively by individuals that originated from freshwater juvenile habitats (Kraus \& Secor 2004b). This result (Fig. 2b) indicates that tidal freshwater may be critical for maintaining a minimum population level during protracted episodes with poor environmental conditions that lead to low recruitment. In addition, the persistence of dominant year-classes (which are primarily brackish in origin) in overlapping generations of adults provides a complementary mechanism for population growth (i.e. the storage effect; Warner \& Chesson 1985). Thus, both habitats function in concert to regulate population dynamics, complicating attempts to establish priority by simply ranking nursery values.

The difficulty in applying the nursery-role concept in this case is partially due to the lack of recognition that habitat use and/or productivity of different habitats may vary significantly on inter-annual or longer time scales. Fishes that have high fecundity, low survival in early life and overlapping generations of adults (iteroparity) often exhibit infrequent anomalously abundant year-classes (i.e. the dominant year-class effect; Hjort 1914, Winemiller \& Rose 1992). These dominant yearclasses can have a profound effect on the standing crop biomass of adults, and for white perch, the typical juvenile patterns of distribution, abundance, and habitatspecific productivity may be altered significantly by dominant year-classes. The possibility that the dominant year-class effect may produce an analogous situation for juvenile habitats in other species is a point that we believe deserves more attention.

Detrimental impacts to littoral environments from canalization by construction of shoreline bulkheads, land reclamation, and dredging are a potential issue for white perch in the Patuxent River and other populations in Chesapeake Bay. Given the results of the nursery value analysis for juvenile white perch habitats, how would one decide (hypothetically) to protect a given square kilometer of freshwater habitat over an equivalent amount of brackish habitat (or vice versa)? We assert that the nursery-role concept provides clear evidence that tidal freshwater habitats should receive conservation priority. Although the absolute contribution of tidal freshwater juvenile habitats to adults is small, this habitat provides a more consistent reproductive subsidy, even during episodes when the contribution from brackish habitats is relatively small or negligible. Further, as measured by nursery value, the impact of eliminating a square kilometer of tidal freshwater littoral habitat would have a disproportionately greater impact than the same action in brackish habitat. This is true because the highest overall nursery value was observed in tidal freshwater habitats during normal years $\left(4.5 \% \mathrm{~km}^{-2}\right)$, and the sum of nursery values across dominant and normal years was greater in freshwater $\left(5.6 \% \mathrm{~km}^{-2}\right)$ than brackish $\left(5.3 \% \mathrm{~km}^{-2}\right)$ habitats. The disparity in size between juvenile white perch habitats was the primary determinant of this result, and in situations where habitats are more equivalent in size (and nursery value still exhibits significant inter-annual variability), the question of assigning conservation priority to different habitats would be far more complicated.

This comparison of nursery value between white perch habitats in the Patuxent River estuary is only one example, and future research to trace fish movements from otolith chemistry will certainly provide data for more rigorous tests of the nursery-role hypothesis. Despite potential problems with the current state of the nursery-role hypothesis, Beck et al.'s (2001) principal contribution was cogently expressing the need to understand connectivity between the habitats of different life stages in marine and estuarine organisms. In our opinion, research in this area of ecology holds the most promise for new insight in spatial population dynamics and for facilitating nursery habitat management and conservation.

Acknowledgements. We are grateful for comments by $\mathrm{M}$. Beck on an early draft, and the manuscript benefited from careful attention of 2 anonymous reviewers. We acknowledge the National Science Foundation (grant No. OEC-9812069) for funding this research. This is contribution 3851 of the University of Maryland Center for Environmental Science.

\section{LITERATURE CITED}

Beck MW, Heck KL, Able KW, Childers DL and 9 others (2001) The identification, conservation and management of estuarine and marine nurseries for fish and invertebrates. Bioscience 51:633-641

Boesch DF (1977) A new look at the zonation of benthos along the estuarine gradient. In: Coull BC (ed) Ecology of marine benthos. University of South Carolina Press, Columbia, SC, p 247-277 
Campana SE, Thorrold SR (2001) Otoliths, increments, and elements: keys to a comprehensive understanding of fish populations? Can J Fish Aquat Sci 58:30-38

Casselman JM (1982) Chemical analyses of the optically different zones in eel otoliths. In: Loftus KH (ed) Proceedings of the 1980 North American Eel Conference. Ontario Fisheries, Technical Report Series, No. 4, Maple, ON, p 74-82

Cronin WB, Pritchard DW (1975) Additional statistics on the dimensions of the Chesapeake Bay and tributaries: crosssection widths and segment volumes per meter depth. Special Report 42, Ref. No. 75-3, Chesapeake Bay Institute, The Johns Hopkins University, Baltimore, MD

Gillanders BM, Kingsford MJ (1996) Elements in otoliths may elucidate the contribution of estuarine recruitment to sustaining coastal reef populations of a temperate reef fish. Mar Ecol Prog Ser 141:13-20

Hjort J (1914) Fluctuations in the great fisheries of Northern Europe. Cons Perm Int Explor Mer 20:1-228

Kraus RT, Secor DH (2004a) Incorporation of strontium in otoliths of an estuarine fish. J Exp Mar Biol Ecol 302:85-106

Kraus RT, Secor DH (2004b) Dynamics of white perch Morone americana population contingents in the Patuxent River estuary, Maryland USA. Mar Ecol Prog Ser 279:247-259

Mansueti RJ (1964) Eggs, larvae, and young of the white perch, Roccus americanus, with comments on its ecology in the estuary. Chesapeake Sci 5:3-45

Editorial responsibility: Kenneth Heck (Contributing Editor), Dauphin Island, Alabama, USA
Odum WE (1988) Comparative ecology of tidal fresh-water and salt marshes. Annu Rev Ecol Syst 19:147-176

Setzler-Hamilton E (1991) White perch, Morone americana. In: Funderbunk SL, Mihursky JA, Jordan SJ, Riley D (eds) Habitat requirements for Chesapeake Bay living resources, 2nd edn. Chesapeake Research Consortium, Solomons, MD, p 12-1-12-20

Ulanowicz RE, Neilson BJ (1974) Segmentation of Chesapeake Bay: a representative exercise. Publication 30, Chesapeake Research Consortium. Contribution No. 626 to the Virginia Institute of Marine Science, Gloucester Point, VA

Wagner CM (1999) Expression of the species minimum in littoral fish assemblages of the lower Chesapeake Bay tributaries. Estuaries 22:304-312

Warner RR, Chesson PL (1985) Coexistence mediated by recruitment fluctuations: a field guide to the storage effect. Am Nat 125:769-787

Winemiller KO, Rose KA (1992) Patterns on life-history diversification in North American fishes: implication for population regulation. Can J Fish Aquat Sci 49:2196-2218

Yamashita Y, Otake T, Yamada H (2000) Relative contributions from exposed inshore and estuarine nursery grounds to the recruitment of stone flounder, Platichthys bicoloratus, estimated using otolith $\mathrm{Sr}$ :Ca ratios. Fish Oceanogr 9: $316-327$

Submitted: July 23, 2004; Accepted: December 2, 2004 Proofs received from author(s): March 30, 2005 